\title{
Article \\ Effects of Field Processing of Sorghum Grain on Popping Traits
}

\author{
Mitchell Kent *(D) and William Rooney (D) \\ Department of Soil and Crop Sciences, Texas A\&M University, College Station, TX 77845, USA; wlr@tamu.edu \\ * Correspondence: makent1995@tamu.edu
}

check for

updates

Citation: Kent, M.; Rooney, W

Effects of Field Processing of Sorghum Grain on Popping Traits. Agronomy 2021, 11, 839. https:// doi.org/10.3390/agronomy11050839

Academic Editor: Miriam Edith Athmann

Received: 21 March 2021

Accepted: 22 April 2021

Published: 24 April 2021

Publisher's Note: MDPI stays neutral with regard to jurisdictional claims in published maps and institutional affiliations.

Copyright: (C) 2021 by the authors Licensee MDPI, Basel, Switzerland. This article is an open access article distributed under the terms and conditions of the Creative Commons Attribution (CC BY) license (https:/ / creativecommons.org/licenses/by/ $4.0 /)$.

\begin{abstract}
Interest in the use of popped sorghum in food products has resulted in a niche market for sorghum hybrids with high popping quality but little work has been done to assess the relative effects of field processing methods of grain on popping quality. This study evaluated the relative effects of harvest moisture and threshing methods on the popping quality of sorghum grain. A grain sorghum hybrid with good popping quality was produced during two different years in Texas wherein it was harvested at two moisture levels (low and high) and grain was removed from panicles using five different threshing methods (hand, rubber belt, metal brushes and two metal concave bar systems). Years, harvest moisture content and threshing method influenced all three popping quality measurements (popping efficacy, expansion ratio and flake size), but threshing method had an order of magnitude larger effect than either moisture level or year. While many of the interactions were significant, they did not influence the general trends observed. As such, the threshing methods with less direct impact force on the grain (hand and rubber belt) had higher popping quality than those samples threshed with greater impact force on the grain (metal-based systems). The popping quality differences between threshing system are likely due to a reduction in kernel integrity caused by the impacts to the kernel that occurred while threshing the grain. The results herein indicate that field processing of the grain, notably threshing method has significant impacts on the popping quality and should be taken into consideration when grain sorghum is harvested for popping purposes.
\end{abstract}

Keywords: sorghum; pop sorghum; pop sorghum processing

\section{Introduction}

Sorghum (Sorghum bicolor L. Moench) is one of several cereal grains such as maize (Zea mays), rice (Oryza sativa), wheat (Triticum) and barley (Hordeum vulgare) that can be popped [1]. Popped sorghum is not a new concept-popping varieties were released over 50 years ago [2] and it has been a popular snack in India and Africa [3]. While it has not been commercialized to a wide extent in the Americas, the popularity of ancient grains in food systems has renewed interest in popped sorghum.

Like popcorn, sorghum produces a generally spherical puffed kernel that is significantly smaller, neutral in flavor, with reduced hulls compared to popped corn [4]. These characteristics provide unique niche market opportunities for popped sorghum. In addition, popped sorghum possesses unique nutritional values compared to grain sorghumpopped sorghum has higher protein and starch digestibility compared to non-popped sorghum [5]. While the interest and demand for popped sorghum has increased, there has been no effort to develop sorghum hybrids with enhanced popping quality.

Similar to popcorn, pop sorghum quality is primarily measured by the expansion ratio (ER) and popping efficiency (PE) [6]. The ER describes the increase in volume of the popped product compared to the initial volume of un-popped grain while PE describes the proportion of kernels that pop after being subjected to the popping method. A third parameter, flake size (FS), describes the size of an individual popped kernel and is important for application in processing. For these traits, popcorn consistently has at least $95 \% \mathrm{PE}$ and ER values as high as 35:1 [7,8]. For comparison, pop sorghum has PE values that average $75-80 \%$ and ER values as high as 11:1 [9,10]. While both traits are lower in sorghum, it 
is not known to what level they can be improved because there are no standards for any popping traits in sorghum.

While biological differences between corn and sorghum affect some of these traits, extraneous factors also influence popping capacity. In popcorn, mechanical damage during harvest (which appears as chipped and cracked kernels) reduces PE [11]. These cracks cause structural weaknesses in the pericarp and endosperm of the kernel and this reduces PE by allowing avenues for the escape of water vapor. Using a razor blade to induce pericarp damage, Singh et al. (1997) reported a 9.1-47.5\% reduction in expansion ratio of damaged popcorn kernels. Similarly, Goneli et al. (2007) [12] reported a reduction in expansion ratio with mechanically damaged popcorn. For these reasons, popcorn is often harvested at higher moisture or by the ear to minimize damage since higher moisture kernels are less prone to structural damage when subjected to mechanical threshing [13]. Similar mechanical damage is possible to occur in sorghum and could affect popping quality.

There are no standard agronomical field processing standards for pop sorghum as there is with popcorn. Currently, sorghum grain that is commercially grown for the purpose of popping is harvested, threshed, and handled the same as sorghum grain for feed, ethanol production or other purposes. If threshing mechanisms affect popping quality in sorghum, then harvest systems for sorghum grain for popping need to be optimized to make pop sorghum a viable market for sorghum grain.

The objectives of this study are to (1) assess the relative effects seed damage caused by varying threshing methods on popping quality traits, (2) asses the effect of harvest moisture on popping quality traits and (3) asses the consistency of these effects across two years.

\section{Materials and Methods}

\subsection{Agronomics}

A single grain sorghum hybrid was grown to produce grain samples for this study. The pollinator parent in the hybrid combination was Tx3489, which was developed by the Texas AgriLife Research sorghum breeding program. This pollinator parent produces hybrids with superior popping quality and agronomic performance comparable to standard grain sorghum hybrids (Table 1). This hybrid was grown in a 0.25 ha block at the AgriLife Research Farm near College Station, Texas in both 2019 and 2020 in a replicated complete block design with two field replications. In both years, trials were rainfed and grown using agronomic practices standard to the region for hybrid grain sorghum production. Fertilizer was applied twice during the growing season-at planting and three weeks afterwards. At the time of planting, $44.8 \mathrm{~kg} / \mathrm{ha}$ of ammonium nitrate and $63.9 \mathrm{~kg} / \mathrm{ha}$ phosphorous was applied. Three weeks after planting, $35.3 \mathrm{~kg} / \mathrm{ha}$ of ammonium nitrate and 12.4 urea was applied.

Table 1. Climatic and agronomic data for the grain of a Texas A\&M pop sorghum hybrid grown in College Station, Texas in 2019 and 2020. Note: LM = low moisture and $\mathrm{HM}=$ high moisture.

\begin{tabular}{|c|c|c|c|c|c|c|c|c|c|c|}
\hline & $\begin{array}{l}\text { Planting } \\
\text { Date }\end{array}$ & $\begin{array}{c}\text { Total } \\
\text { Rainfall } \\
\text { (cm) }\end{array}$ & $\begin{array}{c}\text { Average } \\
\text { Temp } \\
\left({ }^{\circ} \mathrm{C}\right)\end{array}$ & $\begin{array}{l}\text { Low } \\
\text { Temp } \\
\left({ }^{\circ} \mathrm{C}\right)\end{array}$ & $\begin{array}{l}\text { High } \\
\text { Temp } \\
\left({ }^{\circ} \mathrm{C}\right)\end{array}$ & $\begin{array}{l}\text { Average } \\
\text { Dew } \\
\text { Point } \\
\left({ }^{\circ} \mathrm{C} \mathrm{Td}\right)\end{array}$ & $\begin{array}{l}\text { Grain } \\
\text { Yield } \\
\text { (kg/ha) }\end{array}$ & $\begin{array}{c}\text { Plant } \\
\text { Height } \\
\text { (cm) }\end{array}$ & $\begin{array}{l}\text { Days to } \\
\text { Mid An- } \\
\text { thesis }\end{array}$ & $\begin{array}{c}\text { Harvest } \\
\text { Date }\end{array}$ \\
\hline 2019 & $\begin{array}{l}\text { 11th } \\
\text { April }\end{array}$ & 35.3 & 26.7 & 12.5 & 38.3 & 67.5 & 5061.1 & 137.2 & 77 & $\begin{array}{l}3 \text { August } \\
\text { (HM); } \\
11 \text { August } \\
\text { (LM) }\end{array}$ \\
\hline 2020 & 1st April & 27.5 & 25.1 & 14.7 & 35.4 & 66.4 & 6918.9 & 139.7 & 80 & $\begin{array}{l}30 \text { July (HM) } \\
10 \text { August } \\
\text { (LM) }\end{array}$ \\
\hline
\end{tabular}




\subsection{Harvest Moisture and Threshing Methods}

The production block was divided into two field replications. Across replications, grain moisture level was measured using handheld grain moisture reader (Mini Gac 2500, Dickey-John, Auburn, IL, USA). When moisture of the hybrid dropped below 20\%, a high (17-20\%) moisture harvest was completed and when moisture dropped below $15 \%$, a low moisture harvest was completed. In both cases, panicles were hand harvested and collected. Immediately after each harvest, the panicles from each replication were randomly divided and bulked threshed using five different methods; a rubber belt thresher (Almaco BT14); two metal concave threshers (John Deere 3300 combine and Kincaid plot thresher), a metal brush thresher (Winstersteiger LD180), and hand threshing (manual removal of the grain from the panicle). The most notable distinction between the five methods is the difference of materials and force of impact on the kernel during threshing. Hand threshing was low impact, and slow but expected to cause little physical damage to the grain. Belt threshing consistent of two rubber belts at different speed to cause friction to remove the grain from the panicle. The combine, plot thresher and metal brush thresher all relied on metal concave bars or brushes that rotate to knock the seed from the panicle. A minimum of two pounds of grain per field replication was threshed with each method.

\subsection{Popping Evaluation}

After threshing, all threshed grain samples were stored in a cool, dry area for at least three months to allow grain to dry to storage moisture content $(\sim 11-12 \%)$. After moisture stabilization, all samples were prepared for popping assays by tempering grain moisture to $14 \%$ as this is an optimum popping moisture content [14]. After moisture content was adjusted, two 500 kernel samples per field replication were counted for popping assays. These samples were free of glumes and any obvious cracked or broken kernels.

Samples were popped in a residential air popcorn popper (Presto Orville Redenbacher's ${ }^{\circledR}$ Hot Air Popper) for $2 \mathrm{~min}$ at roughly $204^{\circ} \mathrm{C}$. The hot-air poppers were modified to include a mesh screen that kept the sorghum kernels (both popped and unpopped) from blowing out during the popping assay [15]. Because slight variation does occur between poppers, two poppers were used, and each sample was popped twice in each popper for a total of four popping assays. After popping, the total sample volume was measured using a $250 \mathrm{~mL}$ graduated cylinder and was than sieved through a $4.8 \mathrm{~mm}$ screen-kernels that did not pass through the sieve were considered popped and those that passed through were classified as un-popped kernels (UPK). The number of UPK were counted using an electronic seed counter (Old Mill, model 850-3, San Antonio, TX, USA) and the volume was measured using a $25 \mathrm{~mL}$ graduated cylinder. The traits PE and ER were measured following the methods described in Rooney and Rooney (2013) [16] and FS calculations followed methods in Sharma et al. (2014) [17]. Equations used to calculate popping measurements are presented below:

$$
\begin{gathered}
\text { PE }(\%)=\frac{500-\mathrm{UPK}}{500} \times 100 \\
\text { ER }(\mathrm{x}: 1)=\frac{\text { Post Popping Sample Volume } \mathrm{ml}}{\text { Pre Popping Sample Volume } \mathrm{ml}} \\
\text { FS }\left(\mathrm{cm}^{3} / \text { sin gle popped Kernel }\right)=\frac{\text { Post Popping Sample Volume } \mathrm{cm}^{3}}{\text { Number of Popped Kernels }}
\end{gathered}
$$

\subsection{Statistical Analysis}

Analysis of data used JMP ${ }^{\circledR}$, Version 15 (SAS Institute). Normality of the data was assessed using the Shapiro-Wilk test and QQ plots. The residuals ER and FS were determined to be normally distributed under both tests. Based on QQ plot, the residuals of PE were determined to be fairly consistent with the assumption of normality. The statistical model for analysis of each dependent variable (PE, ER and FS) was:

$$
Y=\mu+\alpha_{\mathrm{i}}+\beta_{\mathrm{j}}+\theta_{\mathrm{k}}+\alpha \beta_{\mathrm{ij}}+\beta \theta_{\mathrm{jk}}+\alpha \theta_{\mathrm{ik}}+\alpha \beta \theta_{\mathrm{ijk}}+\pi_{\mathrm{m}}+\nu_{\mathrm{n}}+\delta(\nu)_{\mathrm{pn}}+\varepsilon
$$


where $\alpha=$ threshing method $(i=1,2,3,4,5), \beta=$ harvest moisture $(j=1,2), \theta=$ year $(k=1,2)$, $\pi=$ field replication $(m=1,2), v=$ popper $(n=1,2)$ and $\delta=$ popper replication $(p=1,2)$. A two-way analysis of variance was performed on the data. All independent variables except for replications were considered as fixed effects in order to obtain mean squares and all variables were ran as random to obtain the percent variation explained. The coefficient of variation $(\mathrm{CV} \%)$ was used to determine consistency of data for a measured trait. For traits with significant effects, a means separation of the least square means was conducted using a Student's t test.

\section{Results}

\subsection{Threshing Method, Harvest Moisture and Year}

Of the main effects, threshing method had the largest effect and accounted for the vast majority of variation ( $75.5 \%$ for PE, $68.2 \%$ for ER and $52.6 \%$ for $\mathrm{FS}$ ) observed within this analysis (Table 2). Across the different threshing methods, PE ranged from 63 to 94\%; higher values were associated with the threshing methods that did not have metal to kernel contact; the same trends were observed for ER and FS (Table 3). Harvest moisture did influence all three of the popping traits, but the magnitude of the mean squares is small compared to other effects in this model, explaining less than $2 \%$ of the variation in the model for each popping trait. Of the traits, ER was the most affected by harvest moisture; grain harvested at high moisture increased the ER value by $7.3 \%$. While the year effect was also significant for all three traits the magnitude of the mean squares for them was minimal. For all measured traits, popping quality was consistently higher in 2020 than 2019 but as reflected by the smaller mean squares, the differences were relatively minor. The trait with the largest difference between the two years was PE, which was 3.8\% higher in 2020.

Table 2. Analysis of variance for popping efficacy (PE), expansion ration (ER) and flake size (FS) from the grain of a Texas A\&M pop sorghum hybrid grown in College Station, Texas in 2019 and 2020.

\begin{tabular}{|c|c|c|c|c|c|c|c|}
\hline & & \multicolumn{2}{|c|}{ PE (\%) } & \multicolumn{2}{|c|}{ ER $(x: 1)$} & \multicolumn{2}{|c|}{ FS $\left(\mathrm{cm}^{3}\right)$} \\
\hline Source of Variation & df & \multicolumn{2}{|c|}{ MS } & \multicolumn{2}{|c|}{ MS } & \multicolumn{2}{|c|}{ MS } \\
\hline Threshing Method & 4 & 5947.3 & $* * *$ & 279.3 & $* * *$ & $4.0 \times 10^{-1}$ & $* * *$ \\
\hline Harvest Moisture & 1 & 51.5 & $*$ & 15.1 & $* * *$ & $3.1 \times 10^{-2}$ & *** \\
\hline Year & 1 & 344.6 & $* * *$ & 1.3 & * & $1.2 \times 10^{-2}$ & * \\
\hline Threshing Method $\times$ Harvest Moisture & 4 & 809.9 & $* * *$ & 20.4 & $* * *$ & $1.6 \times 10^{-3}$ & $* * *$ \\
\hline Threshing Method $\times$ Year & 4 & 897.5 & $* * *$ & 27.9 & $* * *$ & $3.6 \times 10^{-2}$ & $* * *$ \\
\hline Harvest Moisture $\times$ Year & 1 & 128.2 & $* *$ & 12.6 & $* * *$ & $2.3 \times 10^{-3}$ & * \\
\hline Threshing Method $\times$ Harvest Moisture $\times$ Year & 4 & 20.2 & ns & 4.2 & $* * *$ & $3.7 \times 10^{-3}$ & $* * *$ \\
\hline Field Replication & 1 & 0.7 & ns & 0.7 & ns & $1.3 \times 10^{-3}$ & ns \\
\hline Popper & 1 & 5.6 & ns & 0.5 & ns & $2.5 \times 10^{-3}$ & * \\
\hline Popper Replication [Popper] & 2 & 23.9 & ns & 0.2 & ns & $1.1 \times 10^{-4}$ & ns \\
\hline Error & 159 & 11.9 & & 0.2 & & $3.6 \times 10^{-4}$ & \\
\hline $\mathrm{R}^{2}$ & & 0.95 & & 0.98 & & 0.97 & \\
\hline $\mathrm{CV} \%$ & & 4.43 & & 5.70 & & 5.10 & \\
\hline
\end{tabular}


Table 3. Threshing method, harvest moisture and year means separation for popping efficacy (PE), expansion ration (ER) and flake size (FS) from the grain of a Texas A\&M pop sorghum hybrid grown in College Station, Texas in 2019 and 2020.

\begin{tabular}{lccc}
\hline & PE (\%) & ER (x:1) & FS (cm $\left.{ }^{\mathbf{3}}\right)$ \\
\hline Threshing Method & & & \\
Hand & $94^{\mathrm{A}}$ & $11.6^{\mathrm{A}}$ & $0.51^{\mathrm{A}}$ \\
Rubber Belt & $90^{\mathrm{B}}$ & $10.5^{\mathrm{B}}$ & $0.47^{\mathrm{B}}$ \\
Combine & $75^{\mathrm{C}}$ & $7.5^{\mathrm{C}}$ & $0.36^{\mathrm{C}}$ \\
Plot Thresher & $67^{\mathrm{D}}$ & $5.6^{\mathrm{D}}$ & $0.30^{\mathrm{D}}$ \\
Metal Brush & $63^{\mathrm{E}}$ & $4.9^{\mathrm{E}}$ & $0.25^{\mathrm{E}}$ \\
\hline Harvest Moisture & & & \\
High Moisture & $78^{\mathrm{A}}$ & $8.3^{\mathrm{A}}$ & $0.36^{\mathrm{B}}$ \\
Low Moisture & $77^{\mathrm{B}}$ & $7.7^{\mathrm{B}}$ & $0.38^{\mathrm{A}}$ \\
\hline Year & & & $0.37^{\mathrm{B}}$ \\
2020 & $80^{\mathrm{A}}$ & $7.9^{\mathrm{A}}$ & \\
2019 & $77^{\mathrm{B}}$ & & \\
Note: Values within a main effect and connected by a common letter within a column are not significantly different \\
at $\alpha=0.05$ using L.S.D.
\end{tabular}

\subsection{Interactions of Threshing Method, Harvest Moisture and Year}

While all three two-way interactions were statistically significant for each of the traits measured, they were much smaller in magnitude than the main effect of threshing (Table 2). The threshing method by year interaction explained the most variation among the three two-way interactions ( $21.7 \%$ for PE, $13.7 \%$ for ER and $13.8 \%$ for FS). The threshing method by harvest moisture interaction explained 19.5\%, 9.4\% and 3.4\% for PE, ER and FS, respectively. The year by harvest moisture interaction was much lower-variation for PE, ER and FS was less than $2 \%$ of the model for all traits. Additionally, the three-way interaction of threshing method, harvest moisture and year was significant for ER and FS, although, the magnitude of this effect was small and there were no trends in this three-way interaction.

\section{Discussion}

The reductions in popping quality caused by threshing methods in sorghum is similar to that reported in popcorn by Singh et al. (1997) and Goneli et al. (2007). In popcorn Lien et al. (1975) [18], reported that popcorn harvested at higher cylinder threshing speeds reduced popping quality. Presumably, higher cylinder speeds would increase more physical damage to the kernels which is a similar relationship a metal versus non-metal threshing approach used in this study.

Hand threshing had the highest values for PE, ER and FS, followed by the rubber belt threshing method while the threshing methods with metal to kernel contact consistently had lower values for all three traits (Table 3). These hand and rubber belt methods of threshing do not involve any contact with metal or other hard surfaces during the threshing process, implying that reduced force or impact during threshing reduces the kernel damage. The other three threshing methods involve metal to kernel contact and presumably greater impact during threshing. Reductions in grain quality due to differences in threshing have been observed in other crops, such has been observed in the difference in rice brewing quality [19]. These results imply that traditional harvesting and threshing methods cause, in some part, the reduction in popping quality seen in sorghum.

The threshed grain used for popping tests were composed of whole, intact kernels with no obvious cracks or chips. Therefore, if kernel damage had occurred, the damage manifests as small cracks or microfractures of the pericarp or endosperm that are not visually obvious. Ultimately, the popping quality of grain sorghum is strongly influenced by the threshing method. This should be taken into consideration when producing sorghum for the intent of popping. 
While differences between the high and low moisture harvests for both PE and FS were significant, the actual differences $\left(1.13 \%\right.$ and $0.03 \mathrm{~cm}^{3}$, for PE and FS, respectively) are of little practical value. As such, harvest moisture is less important than threshing method but harvesting earlier, and drying the grain to storage moisture is generally better than harvest at lower moistures ( $<15 \%$ moisture). These results are consistent with many crops wherein kernel integrity is of importance; harvesting at high moisture is common in rice and popcorn to maintain milled kernel integrity and popping quality, respectively [19].

In the production area for these two years, the weather was relatively consistent, which implies that year to year variation would change if additional or more climatically different years were or had been encountered. Ultimately, the results indicate that the environment influences popping quality of sorghum as it affects grain quality traits in most cereal crops $[20,21]$. As such, it will be important to identify optimum environments for pop sorghum production.

There were several rank shifts associated with the harvest moisture by threshing interaction-most notable is the shift among the combine, plot and metal brush threshing methods (Figure 1). However, this interaction did not affect the top performing threshing methods. Further, interactions involving year (i.e., environment) are typical for crop production; it simply indicates that environmental conditions during the production of the grain influence the popping quality of grain. Similar interactions have been reported in pop sorghum studies such as was observed by Rooney and Rooney (2013).

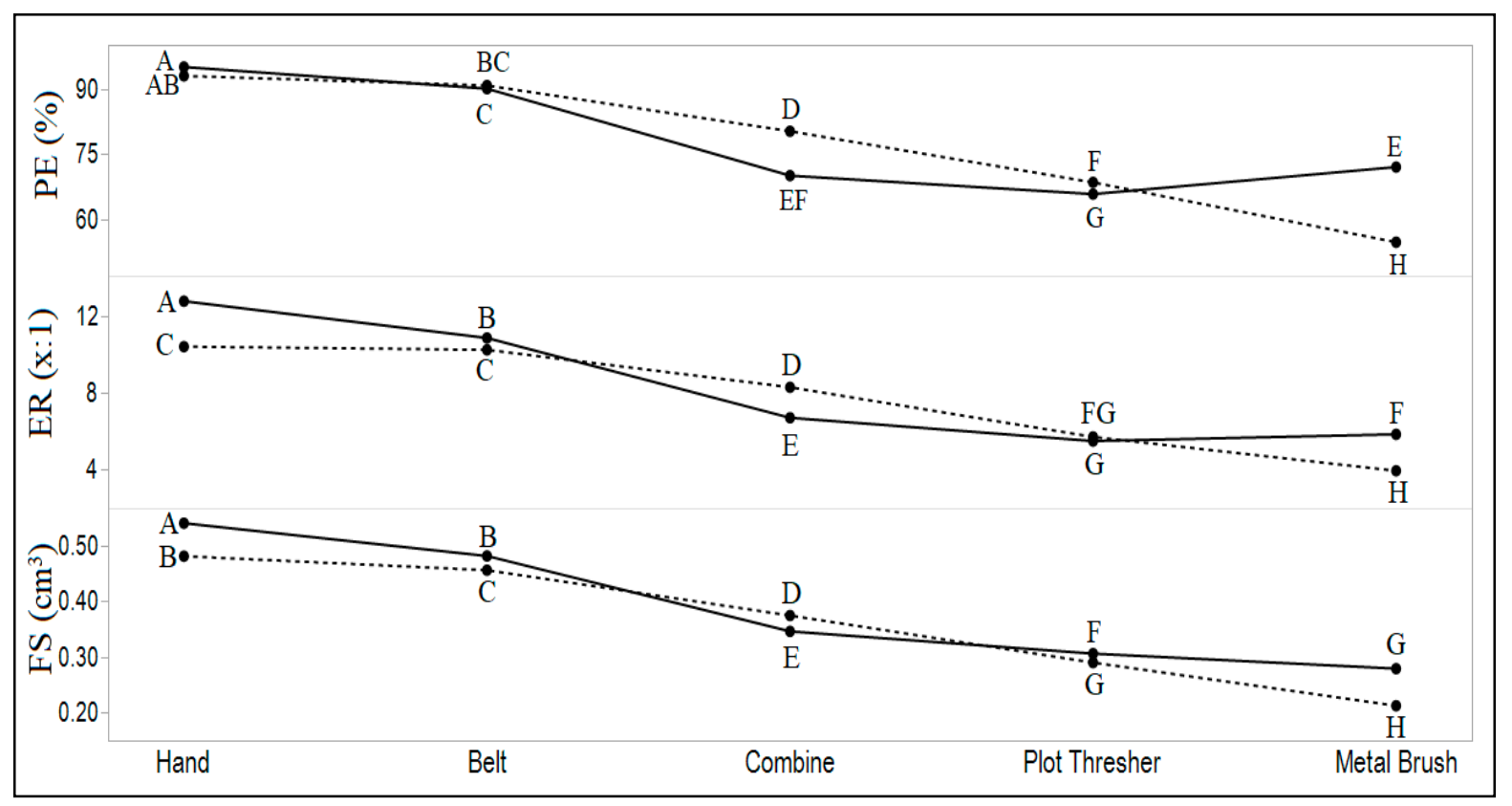

Figure 1. Least square means of popping efficacy (PE), expansion ratio (ER) and flake Size (FS) for the different combinations of threshing method and harvest moistures. The dashed line represents the low moisture harvest, and the solid line represents the high moisture harvest. Connecting letters going across for a given popping trait are not statistically different at $\alpha=0.05$ using L.S.D.

While the significance of the interactions and the interpretations from them do show that they are important, the relative effect is small. The best way to address these factors is for a producer of pop sorghum to try several threshing methods, harvest moisture and environments and decides which combination works best for their operation.

\section{Conclusions}

Of the threshing methods tested affected popping quality traits in sorghum, a clear pattern emerged-threshing methods with metal-to-kernel contact had lower popping quality. The implication is that some threshing methods inflicted kernel damage that 
is manifested in a reduction of popping quality. Ultimately, some form of threshing methodology that reduces impact on the kernel will be beneficial to popping quality in sorghum. Moisture content at harvest has a modest effect on popping quality (specifically FS). The results herein indicate that further investigation of kernel characteristics (i.e., hardness, size, weight, endosperm structure and pericarp thickness) is important and detailed studies of the effect of different levels of impact on kernel integrity are justified.

Author Contributions: Conceptualization, M.K.; methodology, M.K..; software, M.K.; formal analysis, M.K.; data curation, M.K.; writing-original draft preparation, M.K.; writing-review and editing, M.K. \& W.R.; supervision, W.R.; All authors have read and agreed to the published version of the manuscript.

Funding: This research received no external funding.

Institutional Review Board Statement: Not applicable.

Informed Consent Statement: Not applicable.

Data Availability Statement: Data sharing not applicable.

Conflicts of Interest: The authors declare no conflict of interest.

\section{References}

1. Huang, R.; Pan, X.; Lv, J.; Zhong, W.; Yan, F.; Duan, F.; Jia, L. Effects of Explosion Puffing on the Nutritional Composition and Digestibility of Grains. Int. J. Food Prop. 2018, 21, 2193-2204. [CrossRef]

2. Karper, R.E. Registration of Sorghum Varieties, VI 1. Agron. J. 1953, 45, 322-323. [CrossRef]

3. Parker, M.L.; Grant, A.; Rigby, N.M.; Belton, P.S.; Taylor, J.R.N. Effects of Popping on the Endosperm Cell Walls of Sorghum and Maize. J. Cereal Sci. 1999, 30, 209-216. [CrossRef]

4. Rao, K.E.P.; Murty, D.S. Sorghum for special uses. In Proceedings of the International Symposium on Grain Quality ICRISAT, Patacheru, India, 28-31 October 1981; pp. 129-134.

5. Saravanabavan, S.N.; Shivanna, M.M.; Bhattacharya, S. Effect of Popping on Sorghum Starch Digestibility and Predicted Glycemic Index. J. Food Sci. Technol. 2013, 50, 387-392. [CrossRef] [PubMed]

6. Song, A.; Eckhoff, S.R.; Paulsen, M.; Litchfield, J.B. Effects of Kernel Size and Genotype on Popcorn Popping Volume and Number of Unpopped Kernels. Cereal Chem. 1991, 68, 464-467.

7. Lyerly, P.J. Some Genetic and Morphologic Characters Affecting the Popping Expansion of Popcorn 1. Agron. J. 1942, 34, 986-999. [CrossRef]

8. Pordesimo, L.O.; Anantheswaran, R.C.; Fleischmann, A.M.; Lin, Y.E.; Hanna, M.A. Physical Properties as Indicators of Popping Characteristics of Microwave Popcorn. J. Food Sci. 1990, 55, 1352-1355. [CrossRef]

9. Pugh, N.A.; Awika, J.M.; Rooney, W.L. Heritability of Popping Characteristics in Sorghum Grain. Crop Sci. 2017, 57, 71-77. [CrossRef]

10. Aruna, C.; Suguna, M.; Visarada, K.B.R.S.; Deepika, C.; Ratnavathi, C.V.; Tonapi, V.A. Identification of Sorghum Genotypes Suitable for Specific End Uses: Semolina Recovery and Popping. J. Cereal Sci. 2020, 93, 102955. [CrossRef]

11. Singh, V.; Barreiro, N.L.; McKinstry, J.; Buriak, P.; Eckhoff, S.R. Effect of Kernel Size, Location, and Type of Damage on Popping Characteristics of Popcorn. Cereal Chem. 1997, 74, 672-675. [CrossRef]

12. Goneli, A.L.D.; Corrêa, P.C.; Resende, O.; Neto, S.A.R. Electrical Conductivity for Quality Evaluation of Popcorn Kernels Subjected to Mechanical Damage. Biosyst. Eng. 2007, 96, 361-367. [CrossRef]

13. White, G.M.; Ross, I.J.; Poneleit, C.G. Fully-Exposed Drying of Popcorn. Trans. ASAE 1981, 24, 0466-0468. [CrossRef]

14. Gaul, J.A.; Rayas-Duarte, P. Effect of Moisture Content and Tempering Method on the Functional and Sensory Properties of Popped Sorghum. Cereal Chem. 2008, 85, 344-350. [CrossRef]

15. Pugh, N.A.; Rodriguez-Herrera, R.; Klein, R.R.; Klein, P.E.; Rooney, W.L. Identification of Quantitative Trait Loci for Popping Traits and Kernel Characteristics in Sorghum Grain. Crop Sci. 2017, 57, 1999-2006. [CrossRef]

16. Rooney, T.E.; Rooney, W.L. Genotype and Environment Effects on the Popping Characteristics of Grain Sorghum. J. Crop Improv. 2013, 27, 460-468. [CrossRef]

17. Sharma, V.; Champawat, P.; Mudgal, V. Process Development for Puffing of Sorghum. Int. J. Curr. Res. Acad. Rev. 2014, 2, 164-170.

18. Lien, R.M.; Haugh, C.G. The Effect of Field Shelling on Popcorn Quality. Trans. ASAE 1975, 18, 855-858. [CrossRef]

19. Parker, A.M.; Proctor, A.; Eason, R.L.; Jain, V. Effects of Rice Harvest Moisture on Kernel Damage and Milled Rice Surface Free Fatty Acid Levels. J. Food Sci. 2007, 72, C010-C015. [CrossRef]

20. Bassett, L.M.; Allan, R.E.; Rubenthaler, G.L. Genotype $\times$ Environment Interactions on Soft White Winter Wheat Quality. Agron. J. 1989, 81, 955-960. [CrossRef]

21. Argillier, O.; Barriere, Y.; Traineau, R.; Emile, J.C.; Hebert, Y. Genotype x Environment Interactions for Digestibility Traits in Silage Maize Estimated from in Vivo Measurements with Standard Sheep. Plant Breed. 1997, 116, 423-427. [CrossRef] 